\title{
Ovarian Steroid Regulation of Tryptophan Hydroxylase mRNA Expression in Rhesus Macaques
}

\author{
Melanie Pecins-Thompson, Nancy A. Brown, Steven G. Kohama, and Cynthia L. Bethea \\ Divisions of Reproductive Sciences and Neuroscience, Oregon Regional Primate Research Center, Beaverton, Oregon \\ 97006, and Department of Physiology, Oregon Health Sciences University, Portland, Oregon 97201
}

Progesterone $(\mathrm{P})$ stimulates prolactin secretion through an unknown neural mechanism in estrogen $(E)$-primed female monkeys. Serotonin is a stimulatory neurotransmitter in prolactin regulation, and this laboratory has shown previously that $E$ induces progestin receptors $(\mathrm{PR})$ in serotonin neurons. Therefore, we questioned whether $E$ and/or $E+P$ increased serotonin neural function. The expression of mRNA for tryptophan hydroxylase (TPH) was examined in ovariectomized (spayed) control, E-treated (28 d), and E+P-treated monkeys (14 d E and $14 \mathrm{~d} \mathrm{E}+\mathrm{P}$ ) using in situ hybridization and a $249 \mathrm{bp}$ TPH cRNA probe generated with RT-PCR ( $n=5$ animals/group). Densitometric analysis of film autoradiographs revealed a ninefold increase in TPH mRNA in E-treated macaques compared to spayed animals $(p<0.05)$. With supplemental $\mathrm{P}$ treatment, TPH mRNA signal was increased fivefold over spayed animals
( $p<0.05$ ), but was not significantly different compared to E-treated animals. These results were verified by grain counts from photographic emulsion-coated slides. There were significantly higher single-cell levels of TPH mRNA in serotonergic neurons of the dorsal raphe in $\mathrm{E}$ - and $\mathrm{E}+\mathrm{P}$-treated groups $(p<$ 0.05). These data indicate that $E$ induces TPH gene expression in nonhuman primates and that the addition of $P$ has little additive effect on TPH gene expression. Thus, the action of $P$ on prolactin secretion is probably not mediated at the level of TPH gene transcription. However, because $P$ increases raphe serotonin content in E-primed rodents, the possibility remains that $\mathrm{P}$ may have other actions on post-translational processing or enzyme activity.

Key words: tryptophan hydroxylase mRNA; progesterone; estrogen; serotonin; monkey; dorsal raphe
Prolactin release is stimulated by progesterone $(\mathrm{P})$ after estrogen (E) priming in female primates (Williams et al., 1981; Bethea et al., 1996b). This effect of $\mathrm{P}$ on prolactin secretion is probably mediated through a neural mechanism because lactotropes do not contain P receptors (PR) (Sprangers et al., 1989, 1990; Fox et al., 1990). Moreover, the action of $P$ on prolactin is blocked by RU 486 coadministration (Pecins-Thompson and Bethea, 1996). RU 486 is a progestin antagonist that acts only on the nuclear receptor, further implicating the involvement of nuclear PR. Prolactin secretion remains elevated as long as adequate $\mathrm{E}$ and $\mathrm{P}$ are present. We have shown that nuclear PR in the CNS that transduce this effect are also maintained with $\mathrm{E}+\mathrm{P}$ in the primate model (Bethea et al., 1992, 1996a). Currently, the neural pathway(s) by which $\mathrm{P}$ increases prolactin in monkeys is being sought.

$\mathrm{E}$ and $\mathrm{P}$ also play an important role in the modulation of mood or affect. The abrupt decline in $\mathrm{E}$ and $\mathrm{P}$ at the end of the menstrual cycle, after parturition and at the onset of natural or surgical menopause, has been correlated with an increase in negative affect (Mortola et al., 1989; Steiner, 1990). Several authors have suggested that depression associated with changes in

Received May 22, 1996; revised July 9, 1996; accepted Aug. 7, 1996.

Publication \#2012 of the Oregon Regional Primate Research Center. This work was supported by National Institutes of Health Grants HD17269 to C.L.B. and DK9098 to M.P.T., P30 Population Center Grant HD18185, and Grant RR00163 for the operation of the Oregon Regional Primate Research Center. We thank Dr. David Hess, Director of the Population Center Radioimmunoassay Core Laboratory, for the progesterone and estrogen assays. We also thank Jared Cooper of the P30 Morphology Core for assistance with cryosectioning.

Portions of this study were presented at the 5-HT Third IUPHAR Satellite Meeting on Serotonin (1994), the 25th Annual Meeting of the Society for Neuroscience (1995), and IBC's International Conference on Serotonin Receptors (1996).

Correspondence should be addressed to Dr. Cynthia L. Bethea, Oregon Regional Primate Research Center, 505 NW 185th Avenue, Beaverton, OR 97006.

Copyright (C) 1996 Society for Neuroscience $0270-6474 / 96 / 167021-09 \$ 05.00 / 0$ ovarian steroids is related to serotonin (5-HT) neural function (Warren et al., 1979; Glick and Bennett, 1981). However, the mechanism by which $\mathrm{E}$ and $\mathrm{P}$ act on serotonin neurons has not been defined.

In numerous clinical investigations, prolactin secretion has been used as an indicator of serotonin function (Maes et al., 1991), and deficits in prolactin release have been reported for patients with major clinical depression (O'Keane and Dinan, 1991; Anderson et al., 1992). Therefore, understanding the neural pathway by which ovarian steroids regulate prolactin secretion may also reveal important information about the role of ovarian steroids in the neural control of depression.

The serotonin neural system is thought to play a key role in prolactin secretion (van de Kar, 1989; Kordon et al., 1994). Numerous pharmacological studies in rodents reveal a stimulatory effect of serotonin on prolactin (van de Kar, 1989). For example, administration of the serotonin precursor 5-HTP alone or in combination with the uptake inhibitor fluoxetine caused a marked increase in prolactin secretion (Clemens, 1975). In addition, serotonin antagonists for $5-\mathrm{HT}_{1 \mathrm{~b}}$ receptors block prolactin secretion promoted by administration of a serotonin releaser, fenfluramine (van de Kar et al., 1985) or serotonin agonists (van de Kar et al., 1989).

Previous work in this laboratory suggests that serotonin neurons meet several predicted criteria for a neuronal system that could mediate the effect of $\mathrm{P}$ on prolactin. First, serotonin neurons of the raphe nucleus contain nuclear PR (Bethea, 1993). Second, raphe neurons show an induction of PR with $E$ treatment and maintain expression of PR during P treatment (Bethea, 1994). If serotonin neurons mediate the effect of $\mathrm{P}$ on prolactin, then $\mathrm{P}$ treatment should increase the activity of serotonin neurons. We 
previously demonstrated that $\mathrm{P}$ increases the content of serotonin in the dorsal raphe of guinea pigs (Bethea et al., 1995). However, the cellular and molecular mechanism of action of $\mathrm{P}$ in the serotonin neural system is unknown.

PR interact with the genome as transacting factors and, as such, may alter the transcription of important regulatory genes. Tryptophan hydroxylase (TPH) is the rate-limiting enzyme in the synthesis of serotonin, and the regulation of expression of the TPH gene could play a role in serotonergic neurotransmission. The goal of this study was to determine whether $\mathrm{E}$ or $\mathrm{E}+\mathrm{P}$ could increase the expression of TPH mRNA in the dorsal raphe of spayed female monkeys.

\section{MATERIALS AND METHODS}

Animals and experimental groups. This study was approved by the Oregon Regional Primate Research Center (ORPRC) Animal Care and Use Committee. Female rhesus monkeys (Macaca mulatta) were ovariectomized and hysterectomized (spayed) according to previously described procedures (Sprangers et al., 1990) 3-6 months before assignment to this project.

For examination of the regulation of TPH mRNA, 15 previously spayed rhesus monkeys were obtained and processed in five sets. Each set consisted of a spayed control, a spayed female treated with $E$ for $28 \mathrm{~d}$ (E-treated), and a spayed female treated with $\mathrm{E}$ for $28 \mathrm{~d}$ and then supplemented with $\mathrm{P}$ for the final 14 of the $28 \mathrm{~d}$ (E+P-treated).

Surgery and treatments. The spayed monkeys were implanted (s.c.) with one $4.5 \mathrm{~cm}$ E-filled SILASTIC capsule (inner diameter, 0.132 inches; outer diameter, 0.183 inches; Dow Corning, Midland, MI). The capsule was filled with crystalline estradiol [1,3,5(10)-Estratrien-3,17 $\beta$-Diol, Steraloids, Wilton, NH]. Fourteen days after initiation of E treatment, the $\mathrm{E}+\mathrm{P}$-treated group received one $6 \mathrm{~cm}$ capsule filled with crystalline progesterone (4-pregnen-3, 20 Dione, Steraloids). Control monkeys were implanted with empty capsules. All capsules were placed in the periscapular area under ketamine anesthesia (ketamine $\mathrm{HCl}, 10 \mathrm{mg} / \mathrm{kg}$, i.v.; Fort Dodge Laboratories, Fort Dodge, IA).

Blood samples were obtained daily for $28 \mathrm{~d}$ after implantation of the first capsule via saphenous vein puncture within 2 min of transfer to a small transport cage. The samples were obtained between 7:00 and 8:00 A.M. before any other procedures in the animal room. After clotting and centrifugation at $4^{\circ} \mathrm{C}$, serum was harvested and stored at $-20^{\circ} \mathrm{C}$ until assay for prolactin, E, and P levels by RIA.

Tissue preparation. At the end of the treatment period, the monkeys were euthanized according to procedures recommended by the Panel on Euthanasia of the American Veterinary Association. The head of each animal was perfused with $500 \mathrm{ml}$ of saline and 6.51 of $4 \%$ paraformaldehyde. The brain was removed, and a pontine tissue block was obtained and post-fixed for $3 \mathrm{hr}$ in $4 \%$ paraformaldehyde, then washed in $20 \%$ sucrose overnight. The block was trimmed, embedded in Tissue-Tek OCT (Miles Scientific, Naperville, IL), frozen on dry ice, and then stored at $-70^{\circ} \mathrm{C}$. The tissue block containing the raphe was cut in $10 \mu \mathrm{m}$ sections on a cryostat beginning rostrally at the pons and continuing caudally through the cerebellar peduncles. Sections were thaw-mounted on glass slides precoated with gelatin and poly-L-lysine, vacuum-dried overnight, and then stored at $-70^{\circ} \mathrm{C}$. Additional sections for immunocytochemistry (ICC) were thaw-mounted on Superfrost Plus slides (Fischer Scientific, Santa Clara, CA) and stored at $-70^{\circ} \mathrm{C}$.

Hormone assays. Plasma prolactin concentrations were measured as described previously (Bethea and Papkoff, 1986), using an antibody to monkey prolactin (MPRL-5) and a monkey prolactin standard (M21GB) developed in this laboratory. However, iodinated human prolactin (DuPont NEN, Boston, MA) was used instead of iodinated monkey prolactin. The lower limit of detectability of the assay is $6.2 \mathrm{ng} / \mathrm{ml}$. Coefficients of variation within the assays were accepted at $\leq 5.0 \%$ and between the assays at $16.0 \%$.

Plasma $\mathrm{E}$ and $\mathrm{P}$ concentrations were measured as described previously (Resko et al., 1974, 1975). The lower limit of detectability of the E assay is $20 \mathrm{pg} / \mathrm{ml}$. The intra- and interassay coefficients of variation for this assay were 6.6 and $16.4 \%$, respectively. The intra- and interassay coefficients of variation for the $\mathrm{P}$ assay were 7.1 and $15.2 \%$, respectively. The lower limit of detectability of the $\mathrm{P}$ assay is $0.10 \mathrm{ng} / \mathrm{ml}$. For both the $\mathrm{E}$ and the $\mathrm{P}$ assays, the average recovery was $>92 \%$.

The final set of monkeys belonged to another project, and the raphes were donated to this study. Unlike the other four sets, these animals were ovariectomized but not hysterectomized. However, they were treated the same as the other sets with respect to SILASTIC implants of steroid hormones. Because daily blood samples were not collected for the final group, the levels of $\mathrm{E}$ and $\mathrm{P}$ are reported for four of the five sets of monkeys that were perfused and used for in situ hybridization and ICC.

TPH cDNA clone. Total RNA was obtained from the dorsal raphe of a female rhesus macaque at autopsy. The dorsal raphe was dissected in a square piece the width of the central gray from the bottom of the central canal to the decussation of the cerebellar peduncles. For total RNA isolation, the dorsal raphe was extracted in RNAzol B (Tel-Test, Friendswood, TX). The raphe was homogenized with RNAzol B (2 ml/100 mg tissue) with a few strokes in a glass-glass homogenizer. Chloroform $(0.2$ $\mathrm{ml} / 2 \mathrm{ml}$ homogenate) was added, and the sample was covered, shaken vigorously, and placed on ice for $5 \mathrm{~min}$. The suspension was then centrifuged at $12,000 \times \mathrm{g}$ for $15 \mathrm{~min}$. The RNA was transferred to a fresh tube with an equal volume of isopropanol, placed on ice for $15 \mathrm{~min}$, and then centrifuged for $15 \mathrm{~min}$ at $12,000 \times \mathrm{g}$. The supernatant was removed, and the RNA pellet was washed and vortexed. The suspension was centrifuged for $8 \mathrm{~min}$ at $7500 \times \mathrm{g}$ at $4^{\circ} \mathrm{C}$. The pellet was dried briefly and finally dissolved in diethylpyrocarbonate-treated water. RNA was stored for RT-PCR.

The rat TPH cDNA sequence (Kim et al., 1991) is similar in sequence to both tyrosine and phenylalanine hydroxylase at the $3^{\prime}$ catalytic site (Darmon et al., 1988). The $5^{\prime}$ end of each enzyme sequence contains the substrate-binding domain and, therefore, contains the least sequence homology. Forward and reverse primers were constructed from the sequence of rat cDNA that would amplify $\sim 250 \mathrm{bp}$ of the $5^{\prime}$ end of TPH. Oligonucleotide primers (30mers) were synthesized by the ORPRC Molecular Biology Core. The primer sequences were as follows:

Forward: ATGATTGAAGACAACAAGGAGAACAAAGAC Reverse: GTGGGACTTTAGCAGGGGAAAGATGTCATT

RT-PCR was performed in an MJ Research PTC-100 (Watertown, MA). Electrophoresis of the amplification mixture on a $3 \%$ MetaPhor agarose (FMC Bioproducts, Rockland, ME) gel, containing ethidium bromide to visualize the DNA products, yielded a band of the correct size, $\sim 250 \mathrm{bp}$.

The RT-PCR reaction product was then ligated into pCRII (Invitrogen, San Diego, CA), which contains SP6 and T7 promoters on either side of the multiple cloning site. The orientation of the TPH insert was determined by restriction enzyme digestion. The insert was then sequenced in both directions on an automated sequencer (Applied Biosystems 373 DNA Sequencer, Foster City, CA) by the ORPRC Molecular Biology Core for final verification. Riboprobe was synthesized using ${ }^{35}$ S-labeled UTP (DuPont NEN) incorporated into cRNA transcribed from the 5' TPH cDNA (Riboprobe Systems, Promega, Madison, WI). Unincorporated nucleotides were removed by using a Nuctrap push column (Stratagene, La Jolla, CA).

In situ hybridization (ISH). Frozen sections were removed from storage and post-fixed in $4 \%$ paraformaldehyde, rinsed, briefly permeabilized with proteinase $\mathrm{K}(10 \mu \mathrm{g} / \mathrm{ml})$, and then acetylated with acetic anhydride. After rinses and dehydration in ethanol, sections were hybridized overnight at $40^{\circ} \mathrm{C}$ with antisense monkey $5^{\prime}$ TPH probe with $\sim 2.5 \times 10^{5} \mathrm{cpm}$ probe/section. Both sense and antisense cRNAs were generated after the appropriate template linearization. The next morning, sections were washed with $4 \times$ SSC $(0.6 \mathrm{~m}$ sodium chloride, $0.6 \mathrm{~m}$ sodium citrate $)$ containing dithiothreitol $(20 \mathrm{~mm})$, RNase A $(10 \mu \mathrm{g} / \mathrm{ml}), 2 \times \mathrm{SSC}$, and $0.1 \times \mathrm{SSC}$ at $50^{\circ} \mathrm{C}$. Sections were dehydrated, apposed to tritium-sensitive film (Hyperfilm-Bmax, Amersham, Arlington Heights, IL) for $14 \mathrm{~d}$, and then dipped in Kodak NTB-2 emulsion (Eastman Kodak, Rochester, NY) for microscopic evaluation.

Assay specificity. Sense cRNA for TPH was applied to sections of the raphe as a negative control. Also, tissue was pretreated with RNase to destroy all mRNA in the section, which eliminated all specific labeling. Probe specificity was tested by incubating sections of substantia nigra and raphe with the TPH riboprobe verses riboprobe for tyrosine hydroxylase (TH) (Kohama and Bethea, 1995). In addition, sections hybridized to antisense probe were washed at various temperatures to determine the melt-off point. Positive controls for TPH-ISH included antisense hybridization to pineal gland sections.

Autoradiography and histological staining. Slides were dipped in Kodak NTB-2 emulsion that was diluted 1:1 with Milli-Q water and preheated to $45^{\circ} \mathrm{C}$ in a water bath. Slides were air-dried for $30 \mathrm{~min}$ and then dried further in a moist chamber at room temperature for $2 \mathrm{hr}$. Slides were then placed in light-tight boxes containing small tubes of desiccant and ex- 


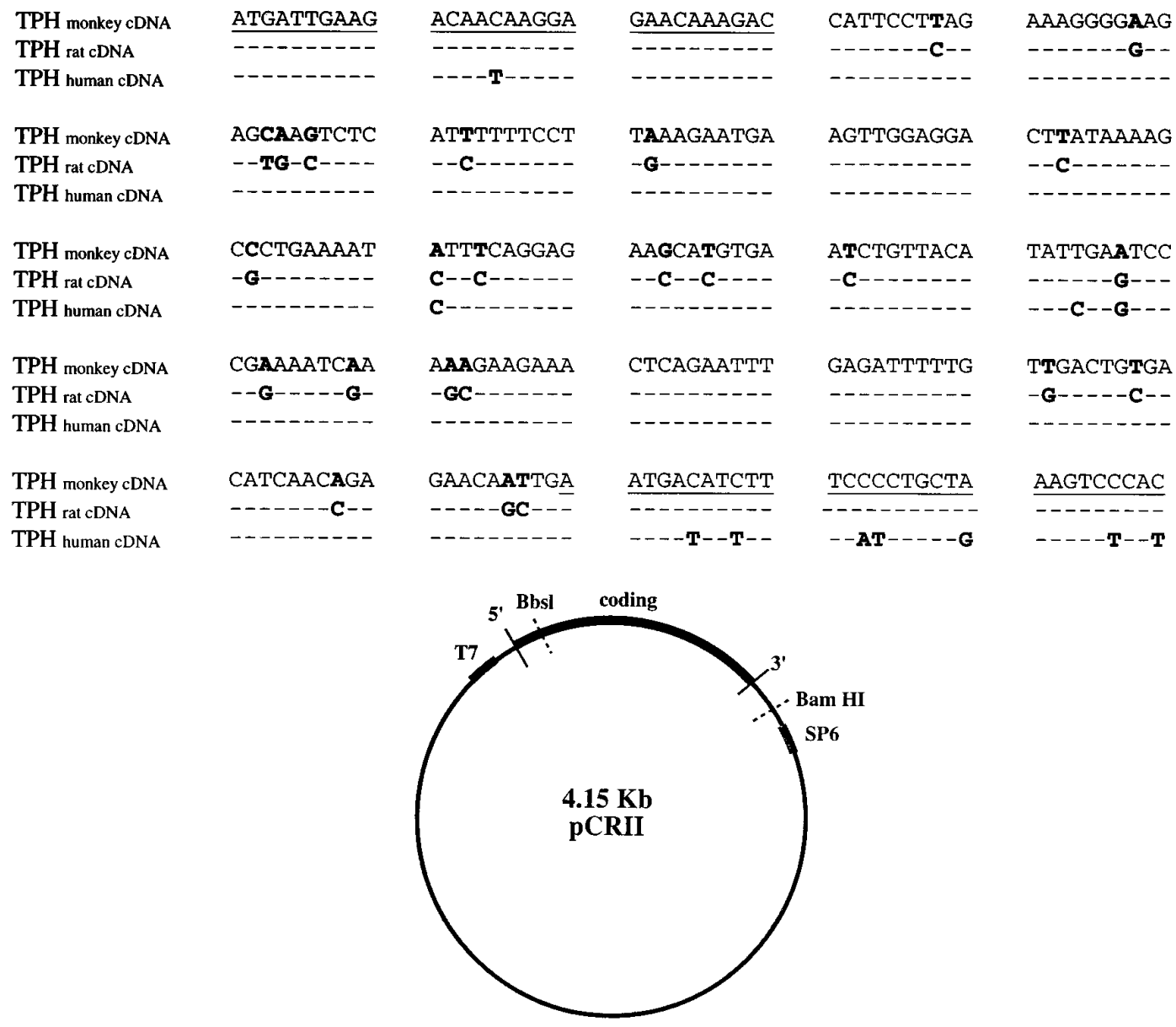

Figure 1. A, Nucleotide sequence of amplified monkey dorsal raphe TPH cDNA compared to rat (Kim et al., 1991) and human TPH (Boularand et al., 1990). The coding sequence is numbered from nucleotide 1. Underlined regions indicate the location of PCR primers. Bold letters indicate differences in the nucleotides between sequences. Nucleotides that are identical to those in monkey TPH appear as dashes. B, Plasmid map of monkey $5^{\prime}$ TPH cDNA showing restriction enzyme recognition and promoter sites. pCR II was the $3.9 \mathrm{~kb}$ plasmid used for ligation of the $0.25 \mathrm{~kb}$ monkey TPH cDNA. The cDNA clone was oriented for antisense transcription by SP6 RNA polymerase and linerized for transcription via a BbsI digest. Restriction endonuclease Bam HI was used to linearize the plasmid for coding sequence. T7 RNA polymerase was then used to make sense cDNA.

posed for 6 weeks at $4^{\circ} \mathrm{C}$. After exposure, they were developed, counterstained with thionin, and coverslips were applied.

Densitometric analysis of hybridization signal. Sections were anatomically matched between animals using the immunolabeled sections as a guide. The anatomical distribution of the immunostained serotonin neurons was closely aligned. The size of the central canal can vary between animals because of handling, freezing, or perfusion pressures. Images from the autoradiographs were captured using a Dage MTI NC-70X camera (Michigan City, IN) and then digitized using the National Institutes of Health Image program. Eight captured frames per field are averaged to form the digitized image. The Image program calculates the total pixel number in an area selected by the operator. The size of the field to be analyzed was set over the dorsal raphe using the E-treated sections. The same field size was then applied to matching sections from spayed and E+P-treated animals of the same set. The number of pixels in the area that reflect specific labeling was then separated from the background (nonspecific labeling) pixels with gray-level thresholding. Threshold levels were set manually by the investigator using the Look Up tool provided in the Image program. After background was removed from total pixel number in the defined area, the percent of pixels that were the result of specific labeling was determined. This was accomplished by dividing the number of pixels above threshold (specific labeling) by the total number of pixels in the field. Densitometric analysis with gray-level thresholding was performed at five morphologically matched levels of the dorsal raphe in each animal from the autoradiographs obtained.

Computer analysis of the hybridization signal. TPH mRNA levels were also determined by counting the number of silver grains over individual neurons from sections processed for ISH. Dark-field microscopic images were video-captured and digitized using a Zeiss IBAS 2000 Image Analysis System equipped with a Zeiss Axioplan microscope with dark-field, $35 \mathrm{~mm}$ photographic capabilities, CCD video camera, and a dedicated image analysis computer with array processor. For each slide, an entire field of background grains was captured to determine both individual grain size and the total grain density caused by nonspecific binding. For grain counts of specific clusters of hybridization, the grains over thioninstained neurons were first located using bright-field illumination. The lighting was then changed to dark-field illumination, and the grains over each neuron were circled, captured, and digitized. Grain number was calculated from the number of positive digitized pixels based on the average grain size. Grain number was then corrected using the predetermined background density. For a neuron to be considered positive for TPH mRNA, the corrected count had to exceed the background density by threefold. To be selected, a cell had to have a thionin-stained nucleus and an isolated cluster of silver grains and to be free of artifacts and debris. Grain counting was performed with a $20 \times$ objective on clusters of grains that lie over isolated cells. Labeled neurons were measured in the dorsal raphe at five levels at $\sim 100 \mu \mathrm{m}$ intervals.

Immunocytochemistry (ICC). Adjacent sections were immunostained for serotonin to confirm the location of the dorsal raphe as described previously (Bethea, 1994). Localization of serotonin was achieved with an avidin-biotin-horseradish peroxidase method using a Vector ABC Kit (Burlingame, CA). Serotonin was identified with a polyclonal rabbit antiserum generated against serotonin conjugated to BSA (1:2000, Incstar, Stillwater, MN). For serotonin ICC, one section was selected every $100 \mu \mathrm{m}$ throughout each block. The slides were rinsed in $80 \%$ ethanol and PBS at $4^{\circ} \mathrm{C}$. Nonspecific binding was blocked with normal goat serum 
Nigra
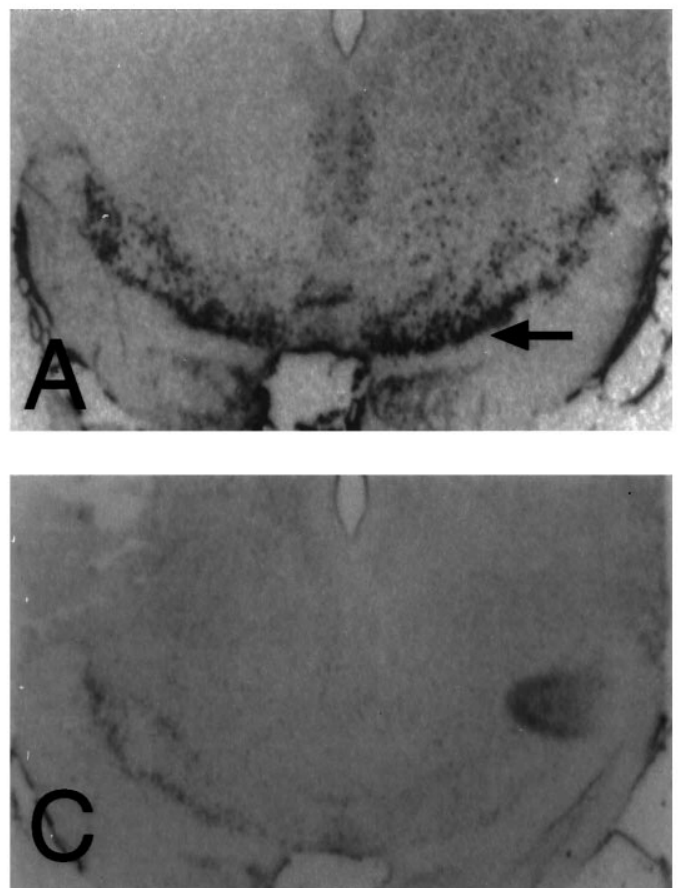

Raphe
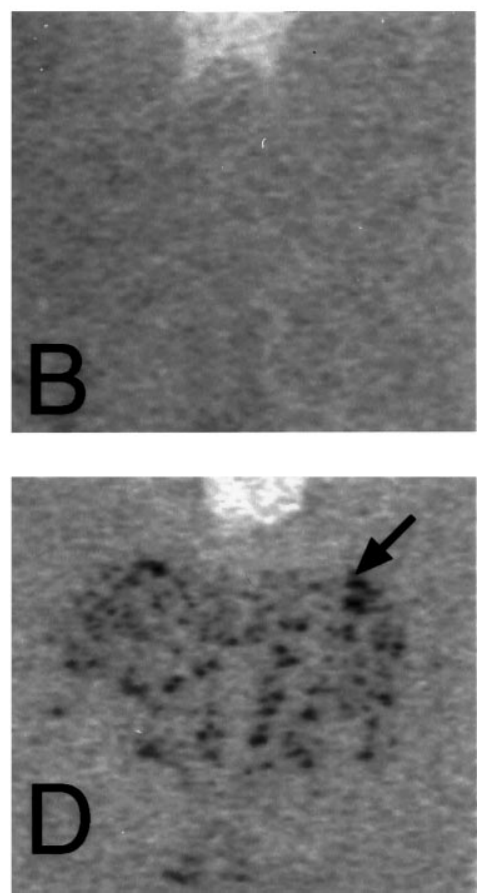

Figure 2. Demonstration of cell specificity for the hybridization of TPH riboprobe in monkey brain. $A$ and $C$ depict sections of substantia nigra. $B$ and $D$ depict sections of raphe. In $A$ and $B$, TH riboprobe was applied to the substantia nigra $(A)$ and the raphe $(B)$. The TH probe hybridized only to the dopaminergic neurons of the nigra as indicated by the black arrow $(A)$. In $C$ and $D$, TPH riboprobe was applied to the substantia nigra $(C)$ and the raphe $(D)$. The TPH riboprobe hybridized only to the serotonergic neurons of the raphe as indicated by the black arrow $(D)$. These are computer-generated images (digitized) of scanned autoradiographs, which are not as sharp as photomicrographs obtained directly through a microscope lens.
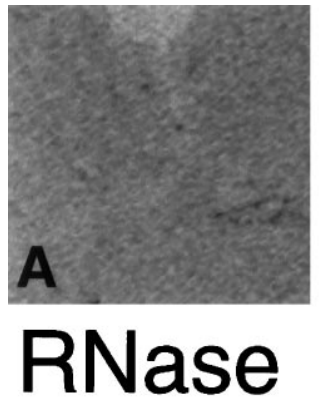

Figure 3. Digitized autoradiographs of control sections. A, Antisense TPH riboprobe applied after RNase pretreatment in the raphe produced no hybridization signal. $B$, No hybridization was observed in the raphe when a sense stand of TPH riboprobe was applied.

(NGS) for $20 \mathrm{~min}$. The sections were drained and incubated overnight at $4^{\circ} \mathrm{C}$ under humid conditions with antiserum to serotonin. The next day, slides were rinsed, reincubated with NGS, and then overlayed with biotinylated goat antirabbit $\mathrm{IgG}$ (Vector) at $20^{\circ} \mathrm{C}$ for $30 \mathrm{~min}$. The second antibody was rinsed off, and the slides were incubated with the ABC-HP reagent. Serotonin antibody labeling was detected by reaction with 0.7 $\mathrm{mg} / \mathrm{ml}$ diaminobenzidine plus $0.006 \% \mathrm{H}_{2} \mathrm{O}_{2}$ for $15 \mathrm{~min}$, yielding a brown deposit over individual serotonin-positive cells. After dehydration through a graded series of ethanols and then xylene, the slides were coverslipped with Permount (Fisher Scientific, Houston, TX).

Statistics. Because of practical and logistic limitations, the 15 monkeys in the TPH mRNA regulation study were processed in sets containing 1 animal from each treatment group. This produced unavoidable set-to-set variation in the grain density. Therefore, the average threshold pixels and number of grains per cell were compared with a Kruskal-Wallis nonpara- metric ANOVA followed by Dunn's multiple comparison test. Steroid hormone concentrations and prolactin were compared with ANOVA and Student-Newman-Keuls pairwise comparison. Data analysis was conducted using the Instat Statistic Program (GraphPad, San Diego, CA). A confidence level of $p<0.05$ was considered significant.

\section{RESULTS \\ Hormone levels}

Radioimmunoassay results are summarized in Table 1. Plasma hormone levels were measured daily for all treatments for $28 \mathrm{~d}$ ( $n=4 /$ treatment group). E levels were compared for the entire period. Prolactin and P levels were statistically compared for the last $14 \mathrm{~d}$ only, after the $\mathrm{P}$ capsule was implanted. Before day 14, both the E- and E+P-treated groups had only E capsules in place and were essentially the same. The E implants raised serum E levels significantly but had no effect on $\mathrm{P}$ or prolactin. The addition of $\mathrm{P}$ implants to the $\mathrm{E}$ regimen significantly elevated $\mathrm{P}$ levels versus spayed and E-treated groups. Prolactin was significantly elevated in the E+P-treated monkeys versus spayed and E-treated monkeys.

\section{TPH clone}

The nucleotide sequence of dorsal raphe 5' TPH cDNA obtained from monkey is shown in Figure $1 A$. The monkey cDNA clone contains $249 \mathrm{bp}$. The monkey clone is $91 \%$ homologous to the rat dorsal raphe TPH cDNA and 95\% homologous to the human dorsal raphe TPH cDNA (Boularand et al., 1990). A plasmid map of monkey 5' TPH cDNA showing restriction enzyme recognition and promoter sites is illustrated in Figure $1 B$. pCRII was the 3.9 $\mathrm{kb}$ plasmid used for ligation of the cDNA. Sense strand cRNA was 


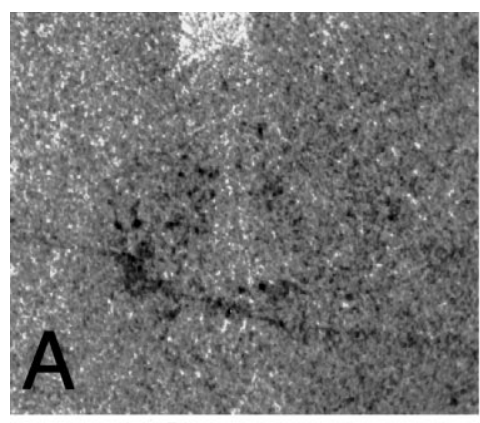

Spayed

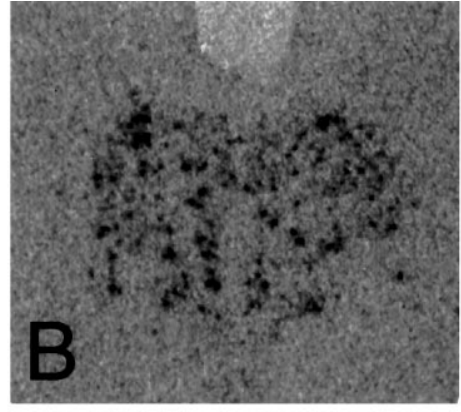

E-treated

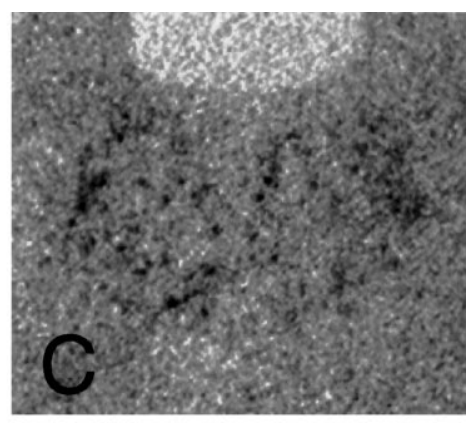

E+P treated

Figure 4. Representative autoradiographs (digitized) from equivalent levels of the dorsal raphe obtained from a spayed, an E-treated, and an $\mathrm{E}+\mathrm{P}$-treated monkey. There appeared to be an increase in TPH mRNA signal as reflected by black pixels in the dorsal raphe of both E- and E $+\mathrm{P}$-treated animals.
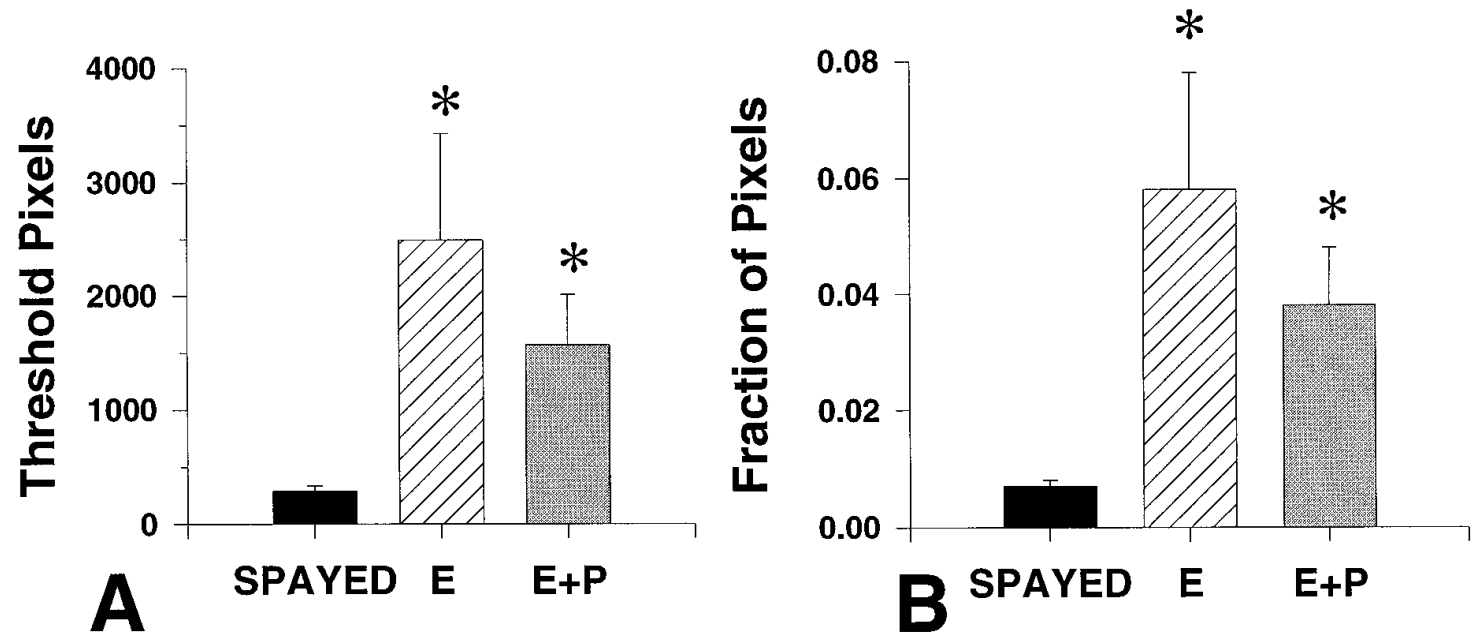

Figure 5. A, Average number of above-threshold pixels measured in spayed and steroid-treated animals $(n=5$ animals/treatment group) with five levels per animal. $B$, The fraction of pixels that are the result of specific labeling in the dorsal raphe over total pixel number in spayed, E-treated, and $\mathrm{E}+\mathrm{P}$-treated animals. Asterisks, Significantly different from spayed; $p<0.05$. There were no significant differences between E- and $\mathrm{E}+\mathrm{P}$-treated groups.

generated from the T7 promoter, and antisense strand cRNA was generated from the SP6 promoter.

\section{ISH controls}

The TPH cRNA probe was highly specific for serotonin neurons. The TPH riboprobe produced hybridization signal only in the serotonin neurons of the dorsal raphe and not in the dopamine neurons of the substantia nigra (Fig. $2 C, D$ ). A TH probe used previously in this laboratory was applied to raphe and nigra sections for comparison (Kohama and Bethea, 1995). The TH riboprobe produced hybridization signal in the dopaminergic neurons of the nigra but not the serotonergic neurons of the raphe (Fig. 2A,B). Pretreatment of the raphe with RNase completely eliminated signal for TPH (Fig. $3 A$ ). No specific labeling was detected when a sense cRNA was applied to dorsal raphe sections (Fig. 3B). Specific labeling decreased when the hybridization temperature was increased above $40^{\circ} \mathrm{C}$. Specific labeling also decreased with wash temperatures of $60^{\circ} \mathrm{C}$ and $70^{\circ} \mathrm{C}$ compared to $50^{\circ} \mathrm{C}$, and it disappeared entirely with a wash temperature of $80^{\circ} \mathrm{C}$.

\section{ISH results}

Representative autoradiographs from equivalent levels of a spayed, E- and E+P-treated monkeys are shown in Figure 4. Within the dorsal raphe, there appears to be an increase in TPH
mRNA signal in both E- and E+P-treated animals. The results of densitometric analysis of the autoradiographs for TPH mRNA are illustrated in Figure 5. Average pixel number was $289 \pm 46$, $2495 \pm 935$, and $1572 \pm 442$ (arbitrary units) for spayed, E-treated, and $\mathrm{E}+\mathrm{P}$-treated groups, respectively (Fig. $5 A$ ). In the raphe, E treatment caused a ninefold increase in TPH mRNA as represented by both positive pixel number (Fig. $5 A$ ) and the fraction of positive pixels (Fig. 5B). Addition of $\mathrm{P}$ did not change the TPH mRNA levels compared to E alone. TPH mRNA in the $\mathrm{E}+\mathrm{P}$-treated group remained significantly higher than in the spayed group.

Representative dark-field photomicrographs of TPH mRNA hybridization autoradiographic grains are shown in Figure 6. TPH mRNA was expressed to a measurable level in spayed (Fig. $6 A, B$ ), E-treated (Fig. 6C,D), and E+P-treated (Fig. 6E,F) animals. Cellular TPH mRNA levels, as reflected by the average number of grains per cell, are shown in Figure 7 in spayed, E-treated, and $\mathrm{E}+\mathrm{P}$-treated monkeys. There were significantly more grains per cell in $\mathrm{E}$ - and $\mathrm{E}+\mathrm{P}$-treated monkeys compared to spayed monkeys (spayed, $24.4 \pm 2.5$ grains/cell; E-treated, $57.5 \pm 9.5$ grains/cell; $\mathrm{E}+\mathrm{P}$-treated, $43.2 \pm 3.4$ grains/cell; $p<0.05$ by ANOVA). E- and $\mathrm{E}+\mathrm{P}$-treated groups were significantly higher than the spayed group $(p<0.05)$ but not different from each other. Figure 8 

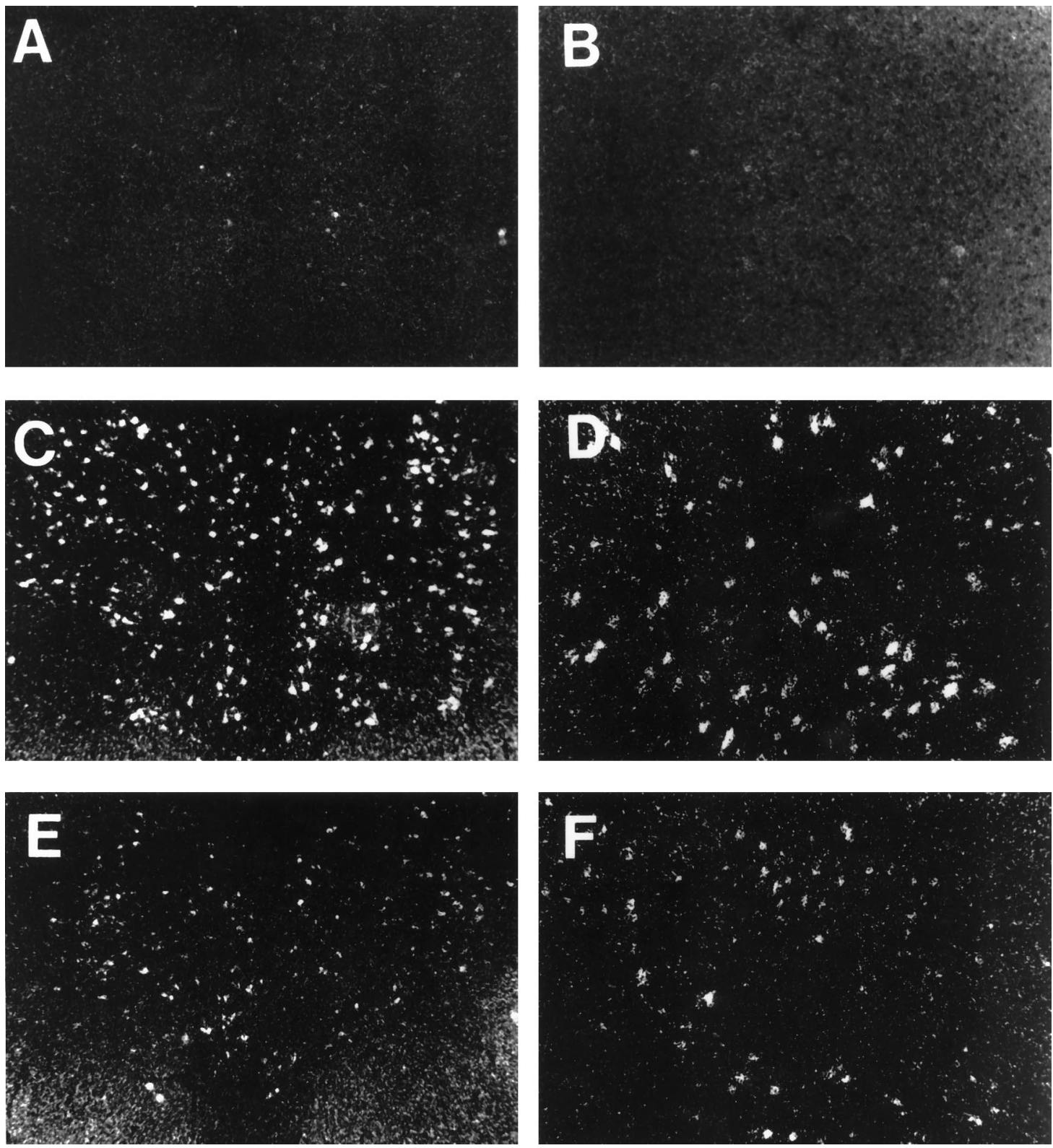

Figure 6. Dark-field photomicrographs of cells of the dorsal raphe that were labeled for TPH mRNA by ISH followed by emulsion development of silver grains. Representative raphes from a spayed $(A, B)$, an E-treated raphe $(C, D)$, and an E+P-treated monkey $(E, F)$ are shown. Magnification: right panels, $12.5 \times$; left panels, $25 \times$.

shows the frequency distribution of grains per cell in spayed, E-treated, and E+P-treated groups. E, with and without P, resulted in a shift to the right of the frequency distribution of signal intensity (grains per cell), further indicating that there are more grains in each positive cell in E- and E+P-treated animals. E, with and without $\mathrm{P}$, also resulted in an increase in the number of cells expressing TPH mRNA.

\section{DISCUSSION}

This is the first documentation of a stimulatory effect of E on TPH gene expression in serotonin neurons in any species, and it impacts our understanding of the role of ovarian hormones in prolactin regulation as well as in depression. The action of $\mathrm{E}$ or $\mathrm{P}$ on TPH mRNA expression may have clinical relevance to the mechanisms involved in depression associated with reproductive function. Spayed macaques are similar to both postmenopausal and postpartum women in that ovarian hormones are close to or below the limit of detectability.

Several lines of evidence indicate that $\mathrm{P}$ may stimulate prolactin via the serotonergic neural system (Bethea, 1994; Kordon et al., 1994; Bethea et al., 1995). However, knowledge of the functional consequences of ovarian steroid action in serotonergic neurons has been needed.

\section{TPH gene expression and prolactin}

In the presence of E, the expression of TPH mRNA is $\sim 10$-fold higher than in spayed macaques. In addition, we observed that the addition of $\mathrm{P}$ to the $\mathrm{E}$ treatment regimen had no significant effect on TPH mRNA expression. E alone has no significant effect on serum prolactin levels, and only when $\mathrm{P}$ is added to ongoing $\mathrm{E}$ treatment are serum prolactin levels elevated (Williams et al., 1981; Bethea et al., 1996b). Therefore, the action of $\mathrm{P}$ on prolactin 


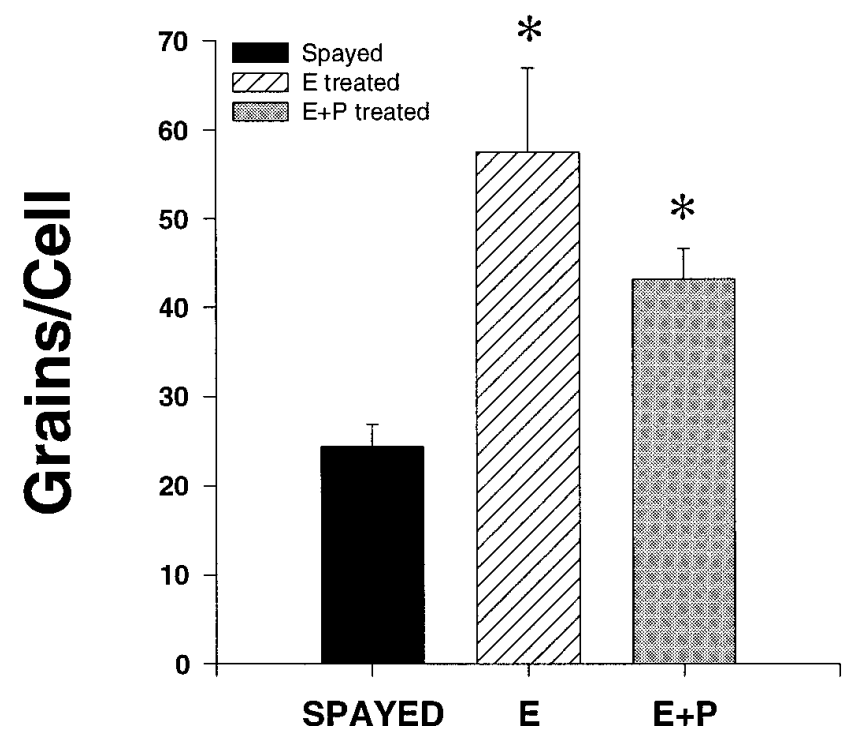

Figure 7. Average number of grains per cell in serotonergic dorsal raphe cells from spayed and steroid-treated monkeys $(n=3$ animals/spayed group; $n=4$ animals/steroid treatment group) with five levels analyzed per animal. There was a significant increase in TPH mRNA with $\mathrm{E}$ and $\mathrm{E}+\mathrm{P}$. Asterisks, Significantly different from spayed group; $p<0.05$. There was no significant difference between $\mathrm{E}$ - and $\mathrm{E}+\mathrm{P}$-treated groups.

secretion is probably not mediated at the level of TPH gene transcription.

A previous study from this laboratory (Bethea et al., 1995) demonstrated that both the serotonin content of the raphe and prolactin secretion are increased in guinea pigs treated with $\mathrm{E}+\mathrm{P}$, but not with $\mathrm{E}$ alone. Hence, prolactin secretion and serotonin levels were positively correlated only when $\mathrm{P}$ was added to the $\mathrm{E}$

\begin{tabular}{llll}
\hline \multicolumn{4}{l}{ Table 1. Serum hormone levels during $\mathbf{2 8} \mathbf{d}$ of steroid treatment } \\
Treatment & $\begin{array}{l}\text { Estrogen } \\
(\mathrm{pg} / \mathrm{ml})\end{array}$ & $\begin{array}{l}\text { Progesterone } \\
(\mathrm{ng} / \mathrm{ml})\end{array}$ & $\begin{array}{l}\text { Prolactin } \\
(\mathrm{ng} / \mathrm{ml})\end{array}$ \\
\hline Spayed & $<20$ & $<0.10$ & $38 \pm 13$ \\
E & $205 \pm 61^{*}$ & $<0.10$ & $85 \pm 25$ \\
E $+\mathrm{P}$ & $213 \pm 40^{*}$ & $6.2 \pm 0.9^{*, * *}$ & $211 \pm 45^{*, * *}$
\end{tabular}

E levels are the average of the $28 \mathrm{~d}$ treatment period. Mean serum $\mathrm{P}$ and prolactin levels during the final $14 \mathrm{~d}$ of steroid treatment ( $n=4$ monkeys/treatment). *, Significantly greater than spay $(p<0.05){ }^{* *}$, significantly greater than $\mathrm{E}$ treatment $(p<0.05)$.

regimen. If $\mathrm{E}$ increases TPH mRNA without changing serotonin levels, then the increase in TPH mRNA with E treatment may not be immediately followed by an increase in serotonin synthesis. Rather, E may drive TPH mRNA synthesis, and addition of P may evoke post-transcriptional events to facilitate serotonin synthesis.

\section{Relation to other studies}

Other information on the relationship between ovarian steroids and serotonin regulation is relatively meager. Studies in rodents found that hypothalamic serotonin turnover increases with $\mathrm{E}+\mathrm{P}$ treatment but not with E alone (Walker and Wilson, 1983; King et al., 1986). In addition, $\mathrm{P}$ partially blocks the effect of pCPA, a serotonin synthesis inhibitor, on hypothalamic serotonin levels, and an antiprogestin reduced hypothalamic levels of 5HIAA, a serotonin metabolite (Walker and Wilson, 1983). Moreover, the proestrus surge of prolactin is inhibited by pCPA treatment, and this effect is completely reversed by $\mathrm{P}$ treatment (Jahn and Deis, 1987). Together, these data support a stimulatory role for $P$ in the regulation of serotonin synthesis.

\section{TPH mRNA Signal}

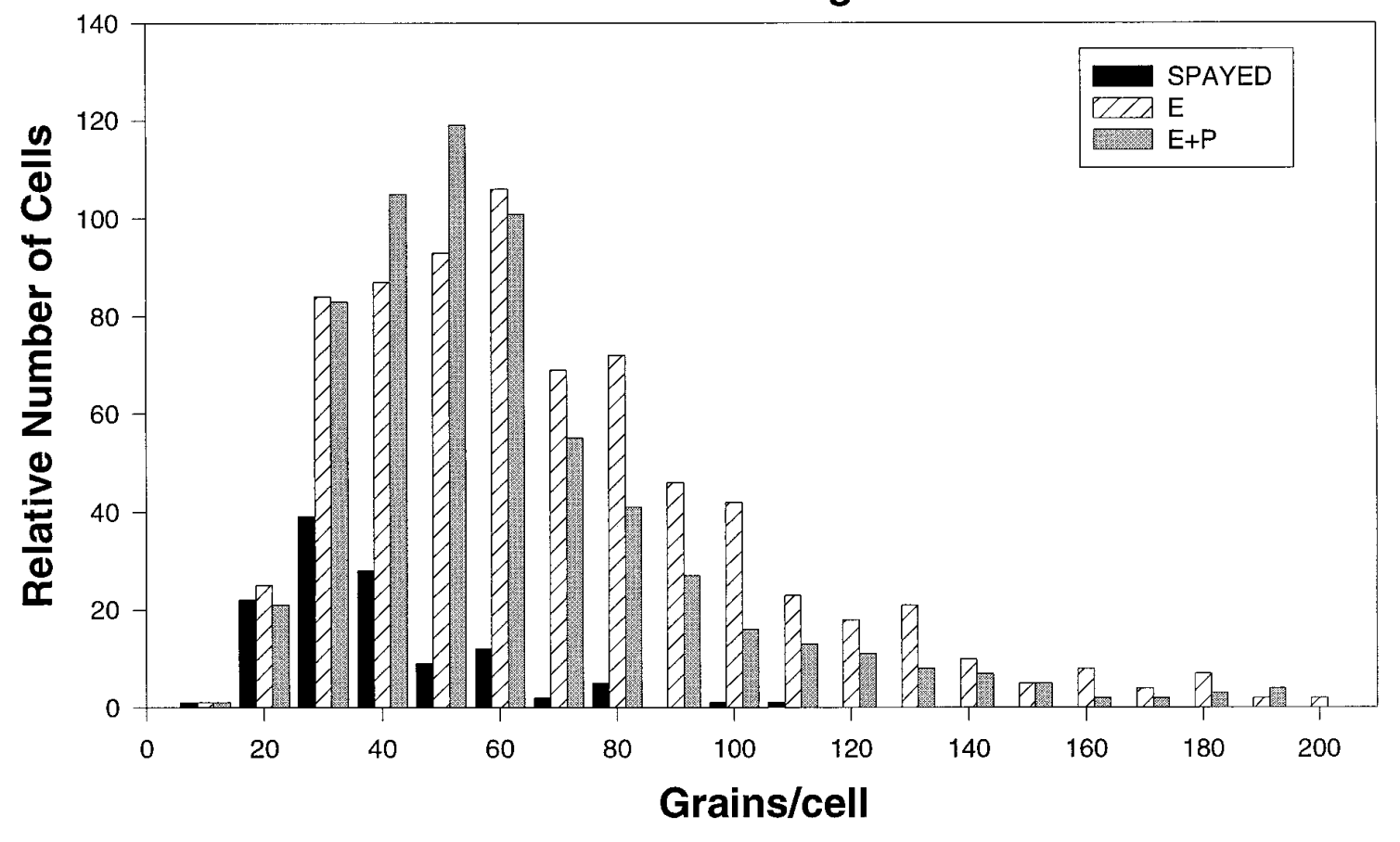

Figure 8. Frequency distribution of TPH mRNA silver grains in neurons of the dorsal raphe of spayed $(n=3)$, E-treated $(n=4)$, and E $+\mathrm{P}$-treated $(n=$ 4) animals. The frequency distribution of the E- and E+P-treated animals is shifted to the right compared with spayed animals, indicating an increase in signal intensity in the steroid-treated groups. E- and E+P-treated groups also had more cells that were positive for TPH mRNA. 


\section{Direct or indirect effects of steroids}

The stimulatory effect of E on TPH mRNA expression may be direct via nuclear $\mathrm{E}$ receptors (ER), or it could be the result of enhanced afferent neurotransmission from another system that is responsive to E. Although ER have not been reported in serotonin neurons, we recently demonstrated that serotonin neurons contain PR, which is markedly induced by E treatment (Bethea, 1994). The induction of PR by $E$ is dependent on nuclear ER in other reproductive tissues and in the hypothalamus (Bethea et al., 1996a). Moreover, in the guinea pig hypothalamus, ER have been colocalized in all neurons containing PR (Blaustein and Turcotte, 1989). Together, these data suggest that serotonin neurons contain nuclear ER. We believe that it is most likely that the stimulatory effect of $\mathrm{E}$ on TPH mRNA expression is mediated directly in the serotonin neuron by nuclear ER. The TPH gene has been cloned in mouse (Stoll and Goldman, 1991; Huh et al., 1994) and human (Boularand et al., 1995), but steroid response elements have not been sought in the promoter region. Nonetheless, our data suggest that an E response element will be found in the 5' regulatory region of the TPH gene.

Evidence is also accumulating that steroids may have rapid, nongenomic actions at the level of the membrane (Ke and Ramirez, 1990; Majewska, 1992) and serotonin neurotransmission may also be modulated in this manner. However, the effect of $\mathrm{P}$ on prolactin secretion appears to require nuclear PR because RU 486 blocks P-induced prolactin secretion (Pecins-Thompson and Bethea, 1996). In addition, prolactin secretion is elevated between 36 and $48 \mathrm{hr}$ after an acute injection of P. This time delay also suggests that transcriptional events may be required.

\section{Other sites of steroid action}

$\mathrm{P}$ may be involved in determining the rate of TPH or serotonin synthesis at a number of other sites along the biosynthetic pathway, including post-translational processing, translation efficiency, or phosphorylation and activation of the TPH enzyme. A difference in the translational efficiency of TPH mRNA has been shown in the raphe versus the pineal gland. The total level of TPH mRNA per milligram of tissue was at least 150 -fold lower in the raphe than in the pineal gland of male rats, but the TPH antigen was 3-fold higher in the raphe than in the pineal (Dumas et al., 1989), suggesting a difference in the translational efficiency of TPH mRNA in the two tissues. This mechanism may be subject to steroid regulation in the raphe.

We have speculated that $\mathrm{P}$ could increase serotonin synthesis by initiating post-transcriptional events. Expanding from this line of reasoning, $\mathrm{P}$ could also act on other genes involved in serotonergic neurotransmission. $\mathrm{P}$ could increase serotonin activity by decreasing transcription of the serotonin reuptake transporter (SERT) gene and/or by downregulation of SERT protein levels. By decreasing SERT, $\mathrm{P}$ would decrease the rate at which serotonin is shuttled out of the synapse and, in turn, this would increase serotonergic neurotransmission. $\mathrm{P}$ could also affect the levels of serotonin receptor expression in target neurons. For example, if stimulatory effects of serotonin are mediated via $5-\mathrm{HT}_{2 \mathrm{~A}}$ or $5-\mathrm{HT}_{2 \mathrm{C}}$ receptors, then target neurons with $\mathrm{PR}$ may exhibit an increase in the expression of these receptors after $\mathrm{P}$ treatment. Finally, $\mathrm{P}$ could decrease expression of the 5- $\mathrm{HT}_{1 \mathrm{~A}}$ autoreceptor and indirectly enhance serotonin neurotransmission. These speculations are currently under investigation.

\section{Ovarian-adrenal interactions}

In rodents, corticosteroids stimulate TPH (Sze et al., 1975). In macaques, plasma cortisol decreases after ovariectomy (Smith and Norman, 1987) and administration of $E$ to ovariectomized rats increases the activity of the hypothalamic-pituitary-adrenal axis and circulating corticosteroids (Kitay, 1961, 1963). Moreover, nuclear receptors for glucocorticoids (GR) are present in serotonin neurons (Harfstrand et al., 1986). Hence, we cannot rule out the possibility that our treatment of spayed macaques with $\mathrm{E}$ caused an increase in cortisol which, in turn, stimulated TPH mRNA levels. In whole animal models such as this one, both direct actions through ER and indirect actions through GR may be operational. Nonetheless, it has been difficult to reconcile many of the experimental observations indicating that corticosteroids increase serotonin neuronal function with the clinical observation that patients with major depression exhibit elevated cortisol (Prange et al., 1977) and an apparent decrease in serotonin neuronal function (Meltzer, 1990).

\section{Serotonin ICC}

In a previous study, we observed that the number of serotonin cells immunolabeled with an antibody to serotonin did not change with $\mathrm{E}$ or $\mathrm{E}+\mathrm{P}$ treatment (Bethea, 1994). However, ICC cannot quantitate the level of serotonin in an individual cell, and even small amounts of serotonin will result in a reaction deposit that is sufficient to label a cell as positive for serotonin. Hence, the previous study in which the number of serotonin neurons did not change with steroid treatment does not reflect on the potential for steroid regulation of pathways leading to serotonin synthesis and neurotransmission.

\section{SUMMARY}

These data indicate that $\mathrm{E}$ treatment can significantly increase levels of TPH mRNA in the dorsal raphe of adult, female monkeys. The data also indicate that the subsequent administration of $\mathrm{P}$ has no additive effect on TPH mRNA expression. This information provides a biological basis for the ability of $\mathrm{E}$ to elevate mood in menopausal women, and it also suggests that P may act elsewhere to increase prolactin secretion.

\section{REFERENCES}

Anderson IM, Ware CJ, Da Roza Davis JM, Cowen PJ (1992) Decreased 5-HT-mediated prolactin release in major depression. Br J Psychiatry 160:372-378.

Bethea CL (1993) Colocalization of progestin receptors with serotonin in the raphe neurons of macaque. Neuroendocrinology 57:1-6.

Bethea CL (1994) Regulation of progestin receptors in raphe neurons of steroid-treated monkeys. Neuroendocrinology 60:50-61.

Bethea CL, Papkoff H (1986) Purification of monkey prolactin from culture medium: biochemical and immunological characterization. Proc Soc Exp Biol Med 182:22-33.

Bethea CL, Fahrenbach WH, Sprangers SA, Freesh F (1992) Immunocytochemical localization of progestin receptors in monkey hypothalamus: effect of estrogen and progestin. Endocrinology 130:895-905.

Bethea CL, Hess DL, Widmann AA, Henningfeld JM (1995) Effects of progesterone on prolactin, hypothalamic $\beta$-endorphin, hypothalamic substance $\mathrm{P}$ and midbrain serotonin in guinea pigs. Neuroendocrinology 61:695-703.

Bethea CL, Brown NA, Kohama SG (1996a) Steroid regulation of estrogen and progestin receptor mRNA in monkey hypothalamus and pituitary. Endocrinology 137:4372-4383.

Bethea CL, Kohama SG, Pecins-Thompson M (1996b) Pituitary and brain actions of estrogen and progesterone in the regulation of primate prolactin secretion. In: Estrogens, progestins and their antagonists in health and disease (Pavlik E, ed), pp 3-45. Boston: Birkhäuser. 
Blaustein JD, Turcotte JC (1989) Estradiol-induced progestin receptor immunoreactivity is found only in estrogen receptor-immunoreactive cells in guinea pig brain. Neuroendocrinology 49:454-461.

Boularand S, Darmon MC, Ganem Y, Launay J-M, Mallet J (1990) Complete coding sequence of human tryptophan hydroxylase. Nucleic Acids Res 18:4257.

Boularand S, Darmon MC, Ravassard P, Mallet J (1995) Characterization of the human tryptophan hydroxylase gene promoter. J Biol Chem 270:3748-3756.

Clemens J (1975) Neuropharmacological aspects of the neural control of prolactin secretion. In: Hypothalamus and endocrine functions (Labrie F, Meites J, Pelletier G, eds), pp 283-302. New York: Plenum.

Darmon MC, Guibert B, Leviel V, Ehret M, Maitre M, Mallet J (1988) Sequence of two mRNAs encoding active rat tryptophan hydroxylase. J Neurochem 51:312-316.

Dumas S, Darmon MC, Delort J, Mallet J (1989) Differential control of tryptophan hydroxylase expression in raphe and in pineal gland: evidence for a role of translational efficiency. J Neurosci Res 24:537-547.

Fox SR, Harlan RE, Shivers BD, Pfaff DW (1990) Chemical characterization of neuroendocrine targets for progesterone in the female rat brain and pituitary. Neuroendocrinology 51:276-283.

Glick ID, Bennett SE (1981) Psychiatric complications of progesterone and oral contraceptives. J Clin Psychopharmacol 1:350-367.

Harfstrand A, Fuxe K, Cintra A, Agnati LF, Zini I, Wilkstrom A-C, Okret S, Yu Z-Y, Goldstein M, Steinbusch H, Verhofstad A, Gustafsson J-A (1986) Glucocorticoid receptor immunoreactivity in monoaminergic neurons of rat brain. Proc Natl Acad Sci USA 83:9779.

Huh SO, Park DH, Cho JY, Joh TH, Son JH (1994) A 6.1 kb 5' upstream region of the mouse tryptophan hydroxylase gene directs expression of $E$. coli lac $\mathrm{Z}$ to major serotonergic brain regions and pineal gland in transgenic mice. Mol Brain Res 24:145-152.

Jahn GA, Deis RP (1987) A possible dual regulation of prolactin release by the serotonergic system in rats at pro-oestrus and during late pregnancy. J Endocrinol 112:367-374.

Ke F, Ramirez VD (1990) Binding of progesterone to nerve cell membranes of rat brain using progesterone conjugated to ${ }^{125} \mathrm{I}$-bovine serum albumin as a ligand. J Neurochem 54:467-472.

Kim KS, Wessel TC, Stone DM, Carver CH, Joh TH, Park DH (1991) Molecular cloning and characterization of cDNA encoding tryptophan hydroxylase from rat central serotonergic neurons. Mol Brain Res 9:277-283.

King TS, Steger RW, Morgan WW (1986) Effect of ovarian steroids to stimulate region-specific hypothalamic 5-hydroxytryptamine synthesis in ovariectomized rats. Neuroendocrinology 42:344-350.

Kitay JI (1961) Sex differences in adrenal cortical section in the rat. Endocrinology 68:818-824.

Kitay JI (1963) Pituitary-adrenal function in the rat after gonadectomy and gonadal hormone replacement. Endocrinology 73:253-260.

Kohama SG, Bethea CL (1995) Steroid regulation of tyrosine hydroxylase messenger ribonucleic acid in dopaminergic subpopulations of monkey hypothalamus. Endocrinology 136:1790-1800.

Kordon C, Drouva SV, Martinez de L'Escaler G, Weiner RI (1994) Role of classic and peptide neuromediators in the neuroendocrine regulation of luteinizing hormone and prolactin. In: The physiology of reproduction (Knobil E, Neill JD, ed), pp 1621-1681. New York: Raven.

Maes M, D'Hondt P, Suy E, Minner B, Vandervorst C, Raus J (1991) HPA-axis hormones and prolactin responses to dextro-fenfluramine in depressed patients and healthy controls. Prog Neuropsychopharmacol Biol Psychiatry 15:781-790.

Majewska MD (1992) Neurosteroids: endogenous bimodal modulators of the $\mathrm{GABA}_{\mathrm{A}}$ receptor: mechanism of action and physiological significance. Prog Neurobiol 38:379-395.

Meltzer HY (1990) The neuropharmacology of serotonin: role of serotonin in depression. Ann NY Acad Sci 600:486-500.

Mortola JF, Girton L, Yen SSC (1989) Depressive episode in premenstrual syndrome. Am J Obstet Gynecol 161:1682-1687.

Pecins-Thompson M, Bethea CL (1996) Fluoxetine augments and mifepristone (RU 486) blocks progesterone-induced prolactin secretion in rhesus macaques. 10th Int Cong Endocrinol 10:304.

Prange Jr AJ, L'ipton MA, Nemeroff CB, Wilson IC (1977) The role of hormones in depression. Life Sci 20:1305-1317.

O'Keane V, Dinan TG (1991) Prolactin and cortisol responses to $d$-Fenfluramine in major depression: evidence for diminished responsivity of central serotonergic function. Am J Psychiatry 148:1009-1015.

Resko JA, Norman RL, Niswender GD, Spies HG (1974) The relationship between progestins and gonadotropins during the late luteal phase of the menstrual cycle in rhesus monkeys. Endocrinology 94:128-135.

Resko JA, Ploem JG, Stadelman HL (1975) Estrogens in fetal and maternal plasma of the rhesus monkey. Endocrinology 97:425-430.

Smith CJ, Norman RL (1987) Influence of the gonads on cortisol secretion in female rhesus macaques. Endocrinology 121:2192-2198.

Sprangers SA, Brenner RM, Bethea CL (1989) Estrogen and progestin receptor immunocytochemistry in lactotropes versus gonadotropes of monkey pituitary cell cultures. Endocrinology 124:1462-1470.

Sprangers SA, West NB, Brenner RM, Bethea CL (1990) Regulation and localization of estrogen and progestin receptors in the pituitary of steroid-treated monkeys. Endocrinology 126:1133-1142.

Steiner M (1990) Postpartum psychiatric disorders. Can J Psychiatry 35:89-95.

Stoll J, Goldman D (1991) Isolation and structural characterization of the murine tryptophan hydroxylase gene. J Neurosci Res 28:457-465.

Sze PY, Neckers L, Towle AC (1975) Glucocorticoids as a regulatory factor for brain tryptophan hydroxylase. J Neurochem 26:169-173.

van de Kar LD (1989) Neuroendocrine aspects of the serotonergic hypothesis of depression. Neurosci Biobehav Rev 13:237-246.

van de Kar LD, Urban JH, Richardson KD, Bethea CL (1985) Pharmacological studies on the serotonergic and nonserotonin-mediated stimulation of prolactin and corticosterone secretion by fenfluramine. Neuroendocrinology 41:283-288.

van de Kar LD, Lorens SA, Urban JH, Bethea CL (1989) Effect of selective serotonin (5-HT) agonists and $5-\mathrm{HT}_{2}$ antagonist on prolactin secretion. Neuropharmacology 28:299-303.

Walker RF, Wilson CA (1983) Changes in hypothalamic serotonin associated with amplification of LH surges by progesterone in rats. Neuroendocrinology 37:200-205.

Warren DE, Tedford Jr WH, Flynn WE (1979) Behavioral effects of cyclic changes in serotonin during the human menstrual cycle. Med Hypotheses 5:359-364.

Williams RF, Barber DL, Cowan BD, Lynch A, Marut EL, Hodgen GD (1981) Hyperprolactinemia in monkeys: induction by an estrogenprogesterone synergy. Steroids 38:321-331. 